The University of San Francisco

USF Scholarship: a digital repository @ Gleeson Library | Geschke Center

2011

\title{
Free Ride, Take It Easy: An Empirical Analysis of Adverse Incentives Caused by Revenue Sharing
}

Daniel A. Rascher

University of San Francisco, RASCHER@USFCA.EDU

Follow this and additional works at: http://repository.usfca.edu/ess

Part of the Sports Management Commons

\section{Recommended Citation}

Rascher, Daniel A., "Free Ride, Take It Easy: An Empirical Analysis of Adverse Incentives Caused by Revenue Sharing" (2011). Kinesiology (Formerly Exercise and Sport Science). Paper 22.

http://repository.usfca.edu/ess/22 


\title{
Free Ride, Take it Easy: An Empirical Analysis of Adverse Incentives Caused by Revenue Sharing
}

\author{
Daniel A. Rascher \\ University of San Francisco \\ Mark S. Nagel and Matthew T. Brown \\ University of South Carolina \\ Chad D. McEvoy \\ Illinois State University
}

\begin{abstract}
A fundamental belief in professional sport leagues is that competitive balance is needed to maximize demand and revenues; therefore, leagues have created policies attempting to attain proper competitive balance. Further, research posits that objectives of professional sport teams' owners include some combination of winning and profit maximization. Although the pursuit of wins is a zero sum game, revenue generation and potential profit making is not. This article focuses upon the National Football League's potential unintended consequences of creating the incentive for some teams to free ride on the rest of the league's talent and brand. It examines whether an owner's objectives to generate increased revenues and profits are potentially enhanced by operating as a continual low-cost provider while making money from the shared revenues and brand value of the league. The present evidence indicates that, overall, being a low-cost provider is more profitable than increasing player salaries in an attempt to win additional games.
\end{abstract}

The ownership of the Cincinnati Bengals has broken the unwritten contract between a team and its fans. The ownership of this organization has actively pursued a course of action which has materially indebted itself to the people of Cincinnati yet has failed to deliver a competitive product. . . The ownership of this organization is causing a lack of balance in the AFC Central and the NFL as a whole. (Mission Statement of MikeBrownSucks.com [Cat, n.d., para.1]).

During the 1990s, the Cincinnati Bengals of the National Football League (NFL) were the worst team in the league, averaging just five wins per season ("Standings," 2008). Mike Brown, owner of the Bengals, is notorious for his unwillingness to spend money to provide fans with a decent on-field product (Daugherty, 2008). However, despite their poor on-field record, the Bengals were the league's fifth most profitable team. Further, additional teams consistently performing poorly on the

Rascher is with the Dept. of Sport Management, University of San Francisco, San Francisco, CA. Nagel and Brown are with the Dept. of Sport and Entertainment Management, University of South Carolina, Columbia, SC. McEvoy is with the School of Kinesiology and Recreation, Illinois State University, Normal, IL. field in this timeframe, such as the Tampa Bay Buccaneers and the Chicago Bears, were also among the NFL's most profitable teams ("NFL team valuations," 2005). Dallas Cowboys owner Jerry Jones noted his displeasure with teams who may be underperforming on the field, while overachieving (compared with league averages) financially due to revenue sharing (Helyar, 2006). Achieving the "optimal" level of revenue sharing has been a discussion in owners' meetings as well as in collective bargaining negotiations with the players (Weisman, 2006).

Similar concerns and anecdotal evidence of greater profits from inferior team performance exists in other major North American sport leagues. Under Donald Sterling's ownership, the Los Angeles Clippers of the National Basketball Association (NBA) has consistently been one of the worst on-the-court teams in the league, yet is reportedly one of the most profitable (Rovell, 2003). Before resigning Elton Brand in 2003, the Clippers had usually either traded or allowed their best players to leave via free agency instead of paying huge salaries to retain their services (O'Sullivan, 2002; Rovell). Despite more than half of the NBA teams making the playoffs each year, the Clippers has only had four playoff appearances since Donald Sterling bought the team in 1981. In 2004, Major League Baseball's (MLB) Tampa Bay Rays, though ranking near the bottom of the league 
in payroll, home attendance, and winning percentage, were the second most profitable team behind the Baltimore Orioles, generating \$27.2 million in operating income (Snel, 2005). The Rays' 2004 profitability was largely due to a $\$ 20$ million subsidy provided by MLB's revenue-sharing program. Further, revenue sharing may actually discourage on-field success and hamper profitability. In 2001, 13 of 16 MLB clubs that were required to contribute to the revenue-sharing pool lost money at the end of the season. The St. Louis Cardinals finished tied for first place in the National League Central division and had income from baseball operations of $\$ 1.9$ million. Under MLB's revenue-sharing model, the Cardinals were required to pay $\$ 8.2$ million into the revenue-sharing pool. This resulted in a $\$ 6.4$ million loss after revenue sharing (Pappas, 2002).

Articles in the popular press and trade publications have specifically discussed the recent profitability "problems" in professional sports and their possible link to league revenue-sharing models (Bloom, 2006; Dosh, 2007). In MLB, critics have noted that even though revenue-sharing dollars are designed to improve team performance, smaller revenue producing franchises have spent the money on any set of expenses or even pocketed it as profit rather than improved their on-field performance (Bloom; Kovacevic, 2005; Snel, 2005; Weir, 2002). For some teams, such as the Pittsburgh Pirates or Milwaukee Brewers, it appears that revenue sharing is creating a disincentive to compete for top players. Those teams have received considerable criticism for continuing to decrease their player payroll despite receiving increased revenue-sharing payments under the Collective Bargaining Agreement (CBA) and generating higher unshared revenues from new facilities (Dosh, 2007).

These anecdotal examples suggest that, in North American sport leagues, it might be possible to increase overall net income by fielding a less expensive, and often less talented, team. When one franchise in a chain of restaurants, for instance, can maintain or even enhance profitability by consistently offering subpar service because the other members of the chain support marketing activities that enhance the brand value, free riding has occurred (Lopatka \& Herndon, 1997). In sport, if a free-rider could reap larger profits than other teams in its league through the decision to decrease operational expenses, the overall brand value of the league could eventually decrease.

The purpose of this study was to empirically test whether free riding exists in the NFL. The NFL was chosen for analysis because it shared approximately $70 \%$ of its overall revenues among its franchises, a greater percentage than any other major North American professional league (Alesia, 2002; Bell, 2004). Just as important is the availability of sufficient NFL data, compared with other leagues, to test these ideas. Lopatka and Herndon (1997) specifically noted the NFL's revenue-sharing model's potential to encourage minimal owner investments in player payroll; "indeed, NFL owners have a greater interest in preventing free riding than do owners of teams in other leagues because of the NFL's unusually high level of revenue sharing" (p. 760). There is certainly the possibility that other leagues have free-riding franchises that lower player quality while generating greater profits, but the NFL's revenue-sharing model and sources of shared revenue (primarily its national television contracts) spurred this investigation. Contrary to previous literature, this article directly tests the impact of free riding on team profits and the resulting incentives involved. While revenue sharing is not necessary to cause free riding, it can serve to enhance the incentives for owners to free ride. This article shows that free riding does exist in the NFL (utilizing 10 years' worth of team level data), and specifically demonstrates which teams are free riding.

Specifically, the article is organized in the following sections. First, the literature review examines professional sports' league structures as well as the specific financial information pertinent to an investigation of the NFL. Next, the article presents the scholarly literature pertaining to free riding in professional sports, followed by a section that develops a theory investigating why free riding results from incentives created by the NFL. The article then presents and discusses data used to examine the theory. Finally, the article provides data analysis, and presents conclusions and a discussion of implications for the NFL as well as other professional sport leagues.

\section{Review of Literature}

Franchises within professional sport leagues operate not as independent organizations desiring to completely eliminate their fellow competitors, but as a quasi-socialist franchisee-franchisor cartel (Scully, 1995). While teams compete on the field, they collaborate in other business activities to maintain the league's overall financial viability. If league owners did not cooperate, it is likely that franchises in smaller cities would not remain financially solvent (Fort, 2003; Harris, 1986; Helyar, 2006). Most North American professional sport leagues have adopted certain activities such as joint marketing campaigns, pooled-debt instruments, and revenue sharing as methods to prevent smaller market teams from being unable to compete with clubs in larger markets (Fort).

Although all franchisee-franchisor companies retain elements of cooperation and minimum standards of performance, professional sport leagues are "peculiar" in that performance (defined by fans as wins) is a zerosum game even though profitability for each franchise is not (Fort, 2003). While consistently negative service quality for one franchise in a McDonald's chain will not negatively affect every store nationwide, in North American professional sports, a team which perpetually loses can negatively impact the overall financial performance of every other franchise-specifically by decreasing overall industry demand (Fort). In addition, where the inadequately performing McDonald's license can be revoked, in professional sports, contraction of poorly 
performing franchises can be met with financial as well as legal difficulties ("MLB at a crossroads...," 2002).

In North American sport leagues, teams equally share revenue from national broadcast rights, Internet advertising, licensed merchandise, and other sources (Brown, Nagel, McEvoy, \& Rascher, 2004). Franchises are permitted to keep local revenue which is typically associated with local broadcast contracts and facility revenues such as luxury suites, parking, and concessions (Foster, Greyser, \& Walsh, 2006). The NFL shares a greater share of its revenues than any other North American league. In particular, where most leagues permit teams to retain general ticketing monies, the NFL takes $40 \%$ of all ticketing revenue and divides it equally among every club (Brown et al., 2004). In addition, since the NFL has no "locally" broadcast regular or postseason games, all television revenues - which averaged $\$ 2.8$ billion a year in 2005 and which increased to over $\$ 4$ billion a year in 2006-are shared equally (Maske, 2005). The NFL generates considerably more money from its television contracts than any other source (Foster et al., 2006).

With such a large portion of shared revenues, many NFL teams have focused their efforts toward developing local revenues that they can retain for themselves rather than share with other franchises (Brown et al., 2004). In most cases, the most effective way to increase unshared revenue is to improve the teams' facility-specifically the unshared revenues that are created through enhanced luxury suite and premium seat sales. This has resulted in teams searching for significantly remodeled or new facilities, often financed by municipalities. Even under the latest collective bargaining agreement ("National Football League...," 2006), where poorer revenuegenerating teams are provided a supplement from the top 15 franchises earning the most from nontelevision and ticketing income, facility revenues remain important. The $\$ 100$ million total amount of this new supplement in 2006 was approximately equal to the disparity between the highest and lowest team revenues in the league that year (Bell, 2006).

In some cases, the lure of the new stadium and its unshared revenue sources has resulted in NFL teams moving from larger markets to smaller ones based upon a "sweetheart" lease arrangement (1995-Los Angeles Rams to St. Louis; 1995-Los Angeles Raiders to Oakland; 1997-Houston Oilers to Nashville [Tennessee] Titans; Barrett, 2003; Donatelli, 2003). However, by choosing to maximize unshared revenues in a smaller metropolitan area, these teams potentially may hurt a shared-revenue source such as the national television contract. In addition, other league-wide revenue sources may not be as lucrative without a team's presence in one of the largest metropolitan communities (Martzke, 2005).

Though there may be attractive options, NFL teams do not have to move to a new metropolitan area to potentially increase revenues and possibly free ride. Throughout the 1990 s and into the early 21 st century the Cincinnati Bengals were consistently one of the most profitable teams because of high revenues from the NFL's national television agreement as well as attendance by diehard fans who continued to purchase tickets despite the team's subpar on-field performance (Daugherty, 2008). The Bengals also enhanced their profitability by not only fielding an inferior on-field product but also by limiting management expenses. For instance, in 2002 the Bengals had 68 employees (not including players) while the Buffalo Bills had 142 employees (Monk, 2002). The Bengals small scouting staff of five (two of whom were family members), paled in comparison with the 15 professional scouts who were employed by the Bills. Moreover, the owner, Mike Brown, doubles as the team's General Manager. Clearly, the ownership presents the appearance that it is not interested in spending money to create a winning team (Daugherty). The Bengals' frugality was believed to be one of the main reasons the NFL Players Association demanded a salary floor when the initial NFL salary cap was implemented in 1993 ("Questions and answers...," 2006). In addition, the limited staff and the team's poor performance caused some fans to launch a negative website titled www.mikebrownsucks.com to voice their displeasure. In general (see Table 1), about $28 \%$ of a team's expenses are not subject to the player salary floor minimum. In other words, these expenses (team expenses plus General and Administrative [G\&A] expenses) divided by player costs plus team expenses plus G\&A expenses are available for the owner to minimize.

The NFL's extensive revenue-sharing system permits the Bengals, or any other team, to keep only a portion of the revenue that an additional dollar spent on marketing generates. Ross (2000) previously noted that even though revenue sharing creates some desirable outcomes, it may also decrease the incentives for teams to promote inperson attendance or merchandise sales. Free riding under an extensive revenue-sharing system may also result in diminished player costs, as the incremental financial effect of improving the team by signing a "star" player is shared with the rest of the league. A revenue-sharing system assumes that each team will maximize its fiscal endeavors to procure the best players and field its best possible team. However, the background and motivation of each owner is different. For some, the team may have been in the family for multiple generations with the team serving as the primary source of income (Harris, 1986). Other owners have achieved financial success in various industries and their foray into professional sports is primarily driven by glory derived from winning rather than the financial bottom line (Wertheim, 2007). Even within the "new breed" of sport owners, the timing of their purchase into the league may impact their debt service and, therefore, their need to generate immediate financial returns. In addition, for some owners, the desired profit margin and/or desire to win may be augmented by public relations considerations (e.g., getting the owner's name in the newspaper, on television). Given the tremendous difference in owner motivation and financial backing, it may be difficult to precisely determine if teams are free riding or simply implementing predetermined spending levels which will meet financial expectations. Regardless 
Table 1 Summary Statistics

\begin{tabular}{lcccc}
\hline Variable & Minimum & Mean & Maximum & Std. Deviation \\
\hline $\begin{array}{l}\text { Population of } \\
\text { MSA or CMSA }\end{array}$ & 191,638 & $5,034,051$ & $10,571,507$ & $5,089,43$ \\
$\begin{array}{l}\text { CMSA equals 1, } \\
\text { MSA equals 0 }\end{array}$ & 0 & 0.5 & 1 & 0.49 \\
Annual Wins & 1 & 7.9 & 1 & 2.95 \\
$\begin{array}{l}\text { Annual } \\
\text { Attendance }\end{array}$ & 123,761 & 481,127 & 635,889 & 80,542 \\
$\begin{array}{l}\text { Year Stadium } \\
\text { Opened }\end{array}$ & 192 & 196 & 199 & 16.2 \\
$\begin{array}{l}\text { Stadium } \\
\text { Capacity }\end{array}$ & 56,692 & 69,785 & 92,516 & \\
$\begin{array}{l}\text { Number of } \\
\text { Major Profes- } \\
\text { sional Sports }\end{array}$ & 1. & 3. & & 7,740 \\
Teams & & & & \\
Local Revenues & $\$ 12,61$ & $\$ 28,61$ & $\$ 83.92$ & \\
$\begin{array}{l}\text { Operating } \\
\text { Revenues }\end{array}$ & $\$ 28,14$ & $\$ 70,01$ & $\$ 189,49$ & $\$ 12,41$ \\
$\begin{array}{l}\text { Player Costs } \\
\begin{array}{l}\text { Operating } \\
\text { Profits }\end{array}\end{array}$ & $\$ 14,70$ & $\$ 41,18$ & $\$ 76,82$ & $\$ 14,19$ \\
$\begin{array}{l}\text { Team Expenses } \\
\text { General and } \\
\text { Administrative } \\
\text { Expenses }\end{array}$ & $\$ 13,602$ & $\$ 6,93$ & $\$ 36,50$ & $\$ 7,80$ \\
\hline
\end{tabular}

Note. All financial information is in $\$ 1,000$ s.

of the owner's motivation, the NFL Players Association (NFLPA) has a vested interest in determining if free riding occurs as free riding may artificially decrease player compensation as players receive $59.5 \%$ of total league revenues under the current CBA ("National Football League ...," 2006).

NFL owners have speculated that some owners are gaining higher profits from their revenue sharing by pocketing money that was designed to be spent on improving overall on-field quality (Helyar, 2006). A few large market teams have even expressed frustration that revenue sharing has resulted in smaller market teams consistently producing greater profits than the higher revenue clubs that generated the revenue to be shared (Helyar). ${ }^{1}$ This certainly was a consideration for the NFL owners' deliberations regarding the most recent CBA and is likely to be an important component of the next CBA ("Jerry Jones fined...," 2009). Determining whether individual teams are truly free riding is difficult given different team's analysis of individual player quality and each team's desire to implement a specific team-building strategy (e.g., acquire free agents, draft players, trade players). However, identifying free riding across the league could lead to changes in the overall revenue-sharing allocation as the league would desire to have a plan that optimizes revenue sharing without compromising team incentives.
There have been several studies regarding free riding and its effects upon a variety of sport-league operations. For instance, Késenne (2000) demonstrated the conditions that allow for revenue sharing to improve competitive balance, decrease competitive balance, or have no effect on competitive balance. His model noted that if the marginal impact of the visiting team on revenues is minimal or similar across teams, then revenue sharing will worsen competitive balance as home teams will have no incentive to improve their quality as their increased revenues will be immediately distributed across the league.

Other authors used models to investigate revenuesharing issues specifically tied to attendance by customers who are purchasing because of the presence of the visiting team (Fort \& Quirk, 1995; Marburger, 1997; Rascher, 1997; Vrooman, 1996). These authors found that increases in revenue sharing will either improve competitive balance in a league or have minimal-to-no-impact on competitive balance. Fort and Quirk noted that additional theoretical and empirical research regarding competitive balance needs to be conducted.

Szymanski and Késenne (2004) demonstrated that revenue sharing makes competitive balance worse. The authors examined gate revenues and the impact of revenue sharing not only on competitive balance but also on the potential total investment in player talent. Their findings 
contrasted with earlier research related to gate revenue sharing and competitive balance in a league. Similarly, Palomino and Rigotti (2000) showed that revenue sharing lowered the incentive for a team to put forth the effort (in terms of spending money to improve team quality) to win. The authors stated, " ... competing hard to win is wasteful" (p. 15). Palomino and Rigotti further noted that the optimal level of revenue sharing is difficult to ascertain.

Although free riding incentives exist in any franchisee-franchisor relationship, the literature demonstrates that revenue sharing in sport leagues can enhance the effects and thus the incentive to free ride. Mason (1997) described the principal-agent problem inherent in the NFL's structure, noting that interests are aligned quite well because of revenue sharing; however, there are still situations where owners' interests diverge. Mason believed the NFL could not effectively merge into a single entity because of the need for contest legitimacy (fan perception that decisions are made by one owner to defeat another owner). Ultimately, sport leagues such as the NFL desire a competitive league with enough revenue sharing to enable every franchise to maintain competitive balance. However, the movement of teams to smaller markets for unshared revenues-which may decrease overall shared revenues-combined with the potential desire of teams with or without new facilities to present a consistently inferior (underpaid) on-field product could create a system where revenue sharing is not the optional mechanism to maximize overall league financial success.

\section{Theory}

The structure of sport leagues, the NFL in particular, is complex from the perspective of incentives and governance. Most businesses have a single principal-agent relationship where the owner (principal) hires employees (agents) to carry out the owner's objectives. The NFL has a dual-layered principal-agent structure, but it is made even more complex by the fact that the principal at the top (the league itself) has, as its ultimate principal, the team owners. The Commissioner retains considerable power in the NFL, but still serves at the discretion of the league's owners. In this structure, the league is a principal trying to maximize the net value of the owners' franchises as a whole, subject to some minimal variation across teams. Each owner is effectively an agent serving the league's objectives. At the franchise level, each owner serves as the principal and hires employees to be the agents to carry out his or her objectives. There is not a true principal at the league level, but instead the group of owners act as their own principal. To make a major change in the league, the NFL requires three-quarters of team owners to agree upon the change. As Mason (1997) suggested, an individual owner may find it in their own interest to relocate to a new city or (as this article analyzes) to offer a low quality, inexpensive product.

Given that there are 32 owners in the NFL with different market sizes, stadiums, lease arrangements, fan bases, and objectives, it is not surprising that some owners would be more interested in profit maximization while others might want to pursue on-field victories and Super Bowl championships. Added to this structure and owner variability is substantial revenue sharing across teams. The amount of revenue sharing is an endogenous factor decided upon by the league itself. To the extent that winning and profitability are aligned, there should not be a principal-agent problem of diverging interests (see Vrooman, 1996). However, winning and profit maximization are not always aligned (Gerrard, 2005).

This article examined one principal-agent issue, whether spending less money operating a franchise (and being a low-cost provider of the product) is more profitable. Profitability is partially based on the brand value and revenue capabilities of the broader league as well as the performance of the individual franchise. A single team can spend less money, offer a low quality product, but still draw fans and share in the national TV contract revenues, all while lowering the overall brand of the league (as Jerry Jones contends). This article does not discuss the effort of agents (franchise employees) in carrying out a team owner's objectives. An NFL franchise can release a football player who is not performing or fire a front office employee who is not providing adequate results. Thus, free riding in this context is not about effort, but about the active decision to spend less money and earn profits based on the brand of the league as a whole and the quality of the other teams in the league.

Given the structure described above, let $\pi$ be the objective function of the NFL. The league's objectives are fluid based on the possibly changing objectives of individual owners. However, the requirement that threequarters of owners must agree to a change tempers the whims of individual owners, yet makes some optimization second best. Let the league maximize

$$
\prod=\prod\left(\sum \pi_{i}(\alpha),-\operatorname{var}\left(\pi_{i}(\alpha)\right)\right)
$$

where $\pi_{\mathrm{i}}$ is the profit of the $i$ th team. Thus, the league tries to maximize the sum of the profits across the teams (total league profitability), but also tries to minimize the variation in profitability across the league. The league chooses $\alpha$ (the percentage of local revenues that the franchise gets to keep) to allow for there to be enough revenue sharing to keep the league intact and prevent any failing franchises. The "-var" shows that the league wants to make the variance of profitability minimal (which is equivalent to maximizing the negative variance). This is a general formulation of the league's objective function and does not specify a model or how much weight is placed on total profitability and the minimization of the variance in profitability. Given that the league is comprised of owners and can only make significant changes with an affirmative vote by three-quarters of the owners, the objective function for the league is actually quite complicated, and this is just one method of formulating it.

As an example, in 2001, MLB announced it was considering the contraction of two of its franchises. The entire league was not experiencing problems, but some 
individual franchises were believed to be experiencing financial difficulty. The contraction option was eventually tabled due to concerns by the MLB Players Association and other entities but the incident displayed how MLB's structure that limited revenue sharing had a negative impact upon some franchises. Therefore, the NFL has multiple objectives including maximizing total league profitability (or league valuation), but also upholding financially struggling franchises.

As described earlier, there are two levels of principals making decisions in the NFL, the league level and the franchise level (or each team owner). Equation (1) describes the league's decision objectives. At the franchise level, an owner maximizes his or her objectives which are a combination of profits and winning (Gerrard, 2005; Rascher, 1997). Thus, the owner maximizes

$$
V_{i}=\delta_{i} \pi_{i}+\left(1-\delta_{i}\right) W_{i}
$$

$\mathrm{Vi}$ is the value to the owner and is a function of that owner's profits $\left(\pi_{\mathrm{i}}\right)$ and winning (Wi). The parameter $\delta \mathrm{i}$ is bounded by 0 and 1 and it represents the importance of those two attributes to owner $i$ 's objectives. Winning and profits are in different units, but without loss of generality, they will both be interpreted as being in monetary units (i.e., one could create a transformation accounting for the amount of winning that equals a certain amount of profit).

The profit function for an NFL franchise shows that the incremental gain from winning more games (which is tied to spending more money in this model) is either positive, negative, or zero and is thus an empirical issue. Let $\pi_{\mathrm{i}}$ be team $i$ 's profit, such that

$$
\pi_{i}=N+\alpha L_{i}\left(W_{i}\right)-C_{i}\left(W_{i}\right)+(1-\alpha) L_{j}\left(W_{j}\right)
$$

where $\mathrm{W}_{\mathrm{i}}$ equals annual franchise wins for team $i, N$ equals national revenues that the franchise receives (and is not based on its own number of wins), (LiWi) is local franchise revenues for team $i$ (and is based on the number of wins for the team), $\alpha$ is the percentage of local revenues that the franchise gets to keep, and $\mathrm{Ci}(\mathrm{Wi})$ is franchise expenses (which are based on team wins under the assumption that winning more games costs more money). Moreover, $\mathrm{L}_{\mathrm{j}}\left(\mathrm{W}_{\mathrm{j}}\right)$ are revenues received from the opposing team when team $i$ travels to team $j$ 's stadium to play. In summary, team $i$ profits from the national TV contract (largely independent of team $i$ 's performance), the share of its local revenues that it gets to keep, the share of the opposing teams' local revenues (here designated as the single team $j$ ), and team $i$ pays a cost to field a team.

Revenue sharing rules during the 1990s in the NFL put $\alpha$ at approximately 0.60 , implying that for each dollar created at the local level, the team shared 40 cents with the league or opposing team directly (Rascher, 1997). As in Gerrard (2005), let

$$
C_{i}=C_{0}+\gamma Q_{i}+\lambda W_{i}
$$

where $\mathrm{C}_{0}$ represents the fixed costs of running the franchise and $\gamma$ is the incremental or marginal cost of purchasing talent (Qi). In other words, $\gamma$ captures the additional expenditures a franchise needs to spend to purchase more talent (i.e., player salaries). There is also an incremental cost to winning $(\lambda)$, such as bonuses for winning and advancing into the playoffs, etc. Equation (5) is $W_{i}=W\left(Q_{i}\right)$. Thus, winning will depend on team quality.

Similarly, let

$$
L_{i}=L_{0}+\beta W_{i}
$$

with $\mathrm{L}_{0}$ representing local revenues that are not tied directly to winning, and $\beta$ capturing the marginal revenue from winning a game.

An interesting aspect of the NFL (and other sport leagues) is that diverging interests between the league and each franchise (or diverging interests across owners as it were) can occur at the high and low ends of expenditures. A free-riding owner would spend as little as possible in fielding a team and maximize profits by saving on costs and sharing in the revenues from the opposing teams. This owner would place a low valuation on $\mathrm{W}_{\mathrm{i}}$ in his or her objective function. This can harm other owners because they will receive less revenue through revenue sharing (and the brand may begin to be harmed).

Alternatively, a high spending owner (who may be relatively more interested in winning than other owners) maximizes his or her objectives by fielding a winning team. However, this can also diverge from the interests of the league and other owners because in spending more money, it can raise the cost of talent by increasing player salaries. This is similar to raising rivals' costs as discussed in the industrial organization literature.

An owner maximizes his or her objective by choosing the quantity of talent $\left(\mathrm{Q}_{\mathrm{i}}\right)$ for the team given the fixed parameters $\alpha, \beta, \gamma$, and $\lambda$. The first order conditions are below. It is solved by taking the derivative of $V_{i}$ with respect to Qi (labeled $V_{i}$ ) in Equation (2) and setting it equal to zero to ensure that the maximum $V$ has been achieved. Let

$$
V_{i}^{\prime}=\delta_{i} \alpha \beta W_{i}^{\prime}-\gamma-\lambda W_{i}^{\prime}+\left(1-\delta_{i}\right) W_{i}^{\prime}=0
$$

Rearranging it as in (7') below, one can see that the lefthand side is the marginal benefit of hiring an incremental unit of talent. That is, one more unit if talent causes winning to rise according to Equation (5), multiplied by the amount that the owner cares about profits $\left(\delta_{\mathrm{i}}\right)$, the percentage of local revenues kept $(\alpha)$, and the impact of winning on revenues $(\beta)$. That is the effect on the profit portion of the value function. An incremental unit of talent also improves winning (again as in Equation (5), and winning itself is valued by the owner according to $\left(1-\delta_{\mathrm{i}}\right)$. Equation (5) is assumed to be upward sloping, but with diminishing returns (a standard assumption).

$$
\delta_{i} \alpha \beta W_{i}^{\prime}+\left(1-\delta_{i}\right) W_{i}^{\prime}=\gamma+\lambda W_{i}^{\prime}
$$

The right-hand side of Equation (7') shows the marginal cost of purchasing one more unit of talent. The direct cost $(\gamma)$ is added to the cost that is based on winning (e.g., performance bonuses or payments for making the playoffs). 
Before conducting the static analysis, it is useful to consider some special cases for comparison. First, if owner $i$ was a profit maximizer who did not care about winning, then $\delta_{\mathrm{i}}$ would be 1 and Equation (7') would reduce to $\alpha \beta W_{i}^{\prime}=\gamma+\lambda W_{i}^{\prime}$ (7"). Further, if the convention in Fort and Quirk (1995) is followed, where talent is defined such that one incremental unit of talent equals one additional win (violating the nonlinearity assumption above), then we have $\alpha \beta=\gamma+\lambda$ (Equation (7"'). Finally, if we assume that there are no bonus payments for winning, then $\alpha \beta=\gamma$ (Equation (7'"'). The empirical section will test this final equation along with direct tests of expenditures on profitability. The more general equations cannot be examined with the empirical data because there is no way to distinguish between the talent level of each team and its number of wins with the data set being used.

For a sport-focused owner (one who strongly desires to win), the marginal cost of purchasing more talent rises as more talent is purchased. Thus, total player payroll and payroll per unit of talent is higher for sport-focused owners. The implication is that there is a tradeoff between maximizing profits and winning, so a free-riding owner (whose primary concern is not winning, but making profits) will hire less talent than a sport-focused owner or one who cares about both winning and profits. This is important because the optimal actions taken will vary across owner type. If it were such that winning as much as possible coincided with profit maximizing, then there would not be a free riding problem because all owners would try to win (and thus maximize profits) as much as possible. This proposition can be seen by noting that as $\delta_{\mathrm{i}}$ decreases (meaning the owner cares more about winning), the LHS of Equation (7') rises (because $\alpha \beta \leq 1$ ), causing the RHS to rise (which is an increase in marginal cost caused by increasing the level of talent). Therefore, being a sport-focused owner is consistent with making less than maximum profits.

A second proposition is that sportsman owners, in their quest to win more games, cause the incremental cost of hiring playing talent to rise for all team owners (not just themselves). This follows from the same analysis above for the sport-focused owner, only that the marginal cost of hiring talent is faced by all team owners.

The league chooses the level of revenue sharing according to its optimization problem (Equation (1)). Higher levels of revenue sharing (lower $\alpha$ ) correspond to a decrease in the marginal benefit from winning (LHS of Equation (7')), so owners purchase less talent, lowering $W_{i}$ (which keeps the LHS equal to the RHS). Further, for profit-maximizing owners, this is even more pronounced. Comparing Equations (7') and (7'), a fixed decrease in $\alpha$ lowers the LHS of Equation (7") more than Equation (7'). Profit-maximizers react more strongly to increased revenue sharing by lowering their talent purchases than do sport-focused owners. In fact, in the extreme if all owners were win maximizers, then $\alpha$ drops out of Equation (7') and revenue sharing has no impact on the decisions of the owners. They all try to buy more talent, bidding up its price.

Sport-focused owners' decisions increase the costs for profit maximizing owners, but is the opposite true? Do profit maximizers who free ride harm sport-focused owners' profits? This is a cross effect of the change in profits for team $i$ from a decrease in talent purchased by team $j$. Using Equations (3), (5), and (6), the derivative of $\pi_{\mathrm{i}}$ with respect to $\mathrm{Q}_{\mathrm{j}}$ is $(1-\alpha) \beta W_{j}^{\prime}$, which is positive. Therefore, a decrease in playing talent by team $j$ (the free rider), lowers the profits of team $i$. In addition, it is exacerbated by increased revenue sharing (lower $\alpha$ ).

In summary, the key theoretical findings are (a) that there is a trade-off between sport-focused owners wanting to win and maximize profits, (b) free riding by one owner will harm the profits of sport-focused owners, (c) higher revenue sharing will cause owners to want to free ride even more than they normally would, (d) if teams are profit-maximizing, then the sensitivity of winning on revenues $(\beta)$ will be equal to the sensitivity of winning on costs $(\gamma$ and $\lambda)$, and (e) if the NFL is structured to create incentives to free ride or keep costs down, then lowered expenses (from player talent acquisition) will raise profits because the revenue effect will be outweighed by the expense effect (from winning). Substantial revenue sharing and the existence of different owner types across the spectrum of profits and winning causes some owners (those who care more about profits than winning) to free ride on the league's brand and talent in the NFL. Two testable hypotheses are summarized in (d) and (e) above.

\section{Methods}

\section{Subjects}

Annual NFL team financial data were gathered for the years 1989-1999 to determine whether free riding exists in the NFL. Data were collected from the conforming financial statements sent by each team to the Commissioner's office and released during The Oakland Raiders v. National Football League (2001) case. Team-specific financial data included local revenues, operating revenues, player payroll, team expenses, G\&A expenses, and operating profit. Of the 319 available observations, 309 (97\%) were useable. More recent data from the NFL are not publicly available. There were some critics of the accuracy of the financial data (Zimbalist, 2001); however, this information was sent from each franchise to the Commissioner and the NFL Board of Governors (made up of some of the team owners) and was used to set NFL policy. As well, its accuracy was not disputed during the trial.

\section{Variables}

Two categories of profits and four categories of expenses were developed. The categories were:

Operating profits-profit reported in the league documents 
Calculated profits—operating revenue minus summary expenses

Player costs-player payroll reported in the league documents

General and administrative expenses-G\&A expenses reported in the league documents

Team expenses-direct team-related expenses such as salaries and other costs associated with coaching, scouting, and training

Summary expenses-the sum of player payroll, G\&A expenses, and team expenses.

To compare data reported over the time frame, a second set of financial variables was created by transforming the financial data into 1998 dollars. Comparisons could then be made across years and across teams, not just across teams for a given year.

The annual number of wins, home game total attendance (including preseason games), the age of the stadium, stadium capacity for football, the number of major professional sport teams (MLB, NBA, National Hockey League (NHL), and NFL) in the local area, and the local MSA (Metropolitan Statistical Area) or CMSA (Consolidated Metropolitan Statistical Area) population were used as control factors in the analysis. These data were collected from sportsline.com, ballparks.com, the U.S. Census Bureau, and individual team websites. The population entry was created by interpolating data from the 1980, 1990, and 2000 censuses. Table 1 outlines the summary statistics for these data, and Table 2 provides correlations.

\section{Procedures}

The data were graphically analyzed across the various combinations of profits, revenues, and expenses. Given that there are two forms of profit (operating and calculated) and four types of expenses (player, general and administrative, team, and summary), eight plots representing all combinations of the data were created. To account for control factors that may skew the graphical results, locally-weighted least squares (LOWESS) regressions were completed. LOWESS regressions essentially run a separate linear regression for each data point using some of the other data points right around it. It then plots a line from that regression, slides over, and does it again with the next data point, until all of the data points have been analyzed. Given that it is a nonparametric method, there are no coefficient estimates produced, but instead a graphical representation of the regression curve is created. The size of the group used for each data point and how

Table 2 Correlation Matrix

\begin{tabular}{|c|c|c|c|c|c|c|c|c|c|c|c|c|c|c|}
\hline Number & Variable & 1 & 2 & 3 & 4 & 5 & 6 & 7 & 8 & 9 & 10 & 11 & 12 & 13 \\
\hline 1 & $\begin{array}{l}\text { Population of } \\
\text { MSA or CMSA }\end{array}$ & 1.00 & & & & & & & & & & & & \\
\hline 2 & $\begin{array}{l}\text { CMSA equals } 1 \text {, } \\
\text { MSA equals } 0\end{array}$ & 0.54 & 1.00 & & & & & & & & & & & \\
\hline 3 & Annual Wins & -0.05 & -0.03 & 1.00 & & & & & & & & & & \\
\hline 4 & $\begin{array}{c}\text { Annual Atten- } \\
\text { dance }\end{array}$ & 0.13 & 0.13 & 0.42 & 1.00 & & & & & & & & & \\
\hline 5 & $\begin{array}{l}\text { Year Stadium } \\
\text { Opened }\end{array}$ & -0.15 & -0.29 & 0.01 & 0.08 & 1.00 & & & & & & & & \\
\hline 6 & $\begin{array}{l}\text { Stadium Capac- } \\
\text { ity }\end{array}$ & 0.30 & 0.00 & 0.09 & 0.45 & -0.16 & 1.00 & & & & & & & \\
\hline 7 & $\begin{array}{c}\text { Number of } \\
\text { Major Profes- } \\
\text { sional Sports } \\
\text { Teams }\end{array}$ & 0.91 & 0.57 & -0.06 & 0.17 & -0.15 & 0.30 & 1.00 & & & & & & \\
\hline 8 & Local Revenues & -0.01 & 0.03 & 0.20 & 0.36 & 0.30 & 0.04 & 0.00 & 1.00 & & & & & \\
\hline 9 & $\begin{array}{l}\text { Operating Rev- } \\
\text { enues }\end{array}$ & -0.02 & -0.01 & 0.12 & 0.25 & 0.26 & 0.01 & 0.00 & 0.87 & 1.00 & & & & \\
\hline 10 & Player Costs & -0.01 & -0.04 & 0.09 & 0.17 & 0.19 & 0.04 & 0.00 & 0.70 & 0.91 & 1.00 & & & \\
\hline 11 & Operating Profits & -0.10 & -0.07 & 0.12 & 0.22 & 0.27 & -0.08 & -0.06 & 0.65 & 0.58 & 0.28 & 1.00 & & \\
\hline 12 & Team Expenses & 0.18 & 0.12 & 0.02 & 0.25 & 0.08 & 0.24 & 0.12 & 0.48 & 0.60 & 0.62 & 0.00 & 1.00 & \\
\hline 13 & $\begin{array}{c}\text { General and } \\
\text { Administrative } \\
\text { Expenses }\end{array}$ & -0.08 & 0.09 & 0.11 & 0.11 & 0.12 & -0.12 & -0.03 & 0.71 & 0.68 & 0.52 & 0.33 & 0.43 & 1.00 \\
\hline
\end{tabular}


much weight is placed on the closer versus further points within that group is chosen by the user. This analysis used bandwidths between 0.4 and 0.8 , meaning that $40-80 \%$ of the data are used, centered on the specific data point that is being estimated. In addition, the weighting mechanism chosen is the standard one developed by Cleveland (1979), who first introduced LOWESS. It is called the tricube weight function and gives no weight to points that are a given distance from the data point in question.

The result of LOWESS is a nonlinear regression line that shows small variations in the data. Because LOWESS uses standard regression techniques over small subsets of the data, it is good at handling outliers by minimizing their effects on the final LOWESS regression line.

It is possible that there is a variable that is correlated with both profit and expenses, such as market size, that is missing from the graphical analysis (i.e., a specification problem). To investigate this, a series of regressions, both linear and polynomial, were completed as well. Generally, only reduced form models with statistically significant variables were reported (not the full models with insignificant variables).

Separately, the parameters $\beta$ and $\gamma$ were analyzed from Equations (4) and (6) by regressing summary expenses on team wins to get $\gamma$, and regressing local revenues on team wins to get $\beta$. The reasons for conducting numerous analyses around the same question is that nonlinear regressions (LOWESS) allow one to see any specific curves or kinks in the data that linear regression smoothes over. However, the nonlinear regressions are not interpretable in terms of incremental impacts (i.e., they do not produce coefficients). Besides understanding what the parameters are, this is the first analysis that directly compares profitability in professional sports to expenditures.

\section{Hypotheses}

It is important to note that compared with the NBA and NHL, the NFL has exhibited lower fitting models of financial variables. Miller (2009) created empirical models of franchise value for the NBA, NHL, and NFL. His goodness-of-fit for the NBA and NHL models were around 0.68 and 0.50 respectively. However, for the NFL models, it was less than 0.28 . One of his reasons given is that there is extensive revenue sharing (driven by the national TV contract) that flattens out revenues across teams regardless of the underlying fundamental differences across winning and population. Similarly, Alexander and Kern (2004) found a positive and significant relationship between franchise values and population for the NBA and NHL, but not for the NFL. Low goodnessof-fit for the profit regressions of NFL franchises is not surprising given the previous finding related to the NFL and related to estimating profit functions as opposed to revenue functions.

This notion is related to one of the points of this article, that the NFL purposefully shares revenues regardless of the nature of each team's market or winning prospects to minimize the risk for franchise owners. The league realizes that each owner is in business together (not competitors) in many ways and it is in the interests of the league as a whole to minimize the financial risk. Statistically, this causes the dependent variable to have low variance, thus there is not much variation for the explanatory variables to explain.

As discussed in the theoretical section, it is expected that $\beta \geq \gamma$ because the financial gain from winning ought to be at least as high as the financial cost (under the assumption that $\lambda=0$, or that the playoff payments to players is de minimis). In addition, it is expected that $\alpha \beta$ $-\gamma$ will be near zero relative to the size of $\alpha$ and $\beta$ (based on profit maximization) or negative to keep league costs down. This will also be investigated directly by considering the relationship between expenses and profits (is that relationship negative, as expected to minimize leaguewide costs or is that relationship positive?).

\section{Analysis and Results}

Free riding in a sport league occurs when a team is able to generate increased profits by offering a lower quality on-field product. An NFL owner is potentially able to free ride because of the NFL's brand value and its substantial revenue-sharing policy. Figures $1 \mathrm{a}-1 \mathrm{~h}$ contain scatter plots of the two profit measures versus the four expense categories using the inflation-adjusted variables. They also contain a linear fitted line from a linear regression along with $95 \%$ confidence intervals.

As can be seen in the figures, franchises with lower player payrolls, lower team expenses, or lower summary expenses typically have higher profits. There does not appear to be a relationship between G\&A expenses and profits. This is not surprising given that the variance among teams for G\&A expenses is minimal.

Figures $2 \mathrm{a}-2 \mathrm{~h}$ contain LOWESS graphs of the inflation-adjusted profit versus expenses. Since LOWESS is a nonparametric analysis, instead of an equation, graphs of the fitted relationship are created. The relationships are relatively linear indicating that a linear regression is a reasonable approximation of the true relationship between the variables. However, the graph of adjusted operating profits versus adjusted summary expenses is U-shaped. The U-shape indicates that profit can be made by either free riding via lower expenses or by spending enough money to improve winning and attendance so that revenues are increased at a greater rate than costs. This is accounted for in the corresponding linear regressions in Tables 3 and 4.

As a variable could be correlated with profits and expenses, a series of regressions, both linear and polynomial, were completed. The two inflation-adjusted calculated profits models in Table 3 demonstrate that player payroll and summary expenses are negatively related to profit at the .01 level of statistical significance. The results are economically as well as statistically significant. A $\$ 1$ million increase in player payroll is associated with 

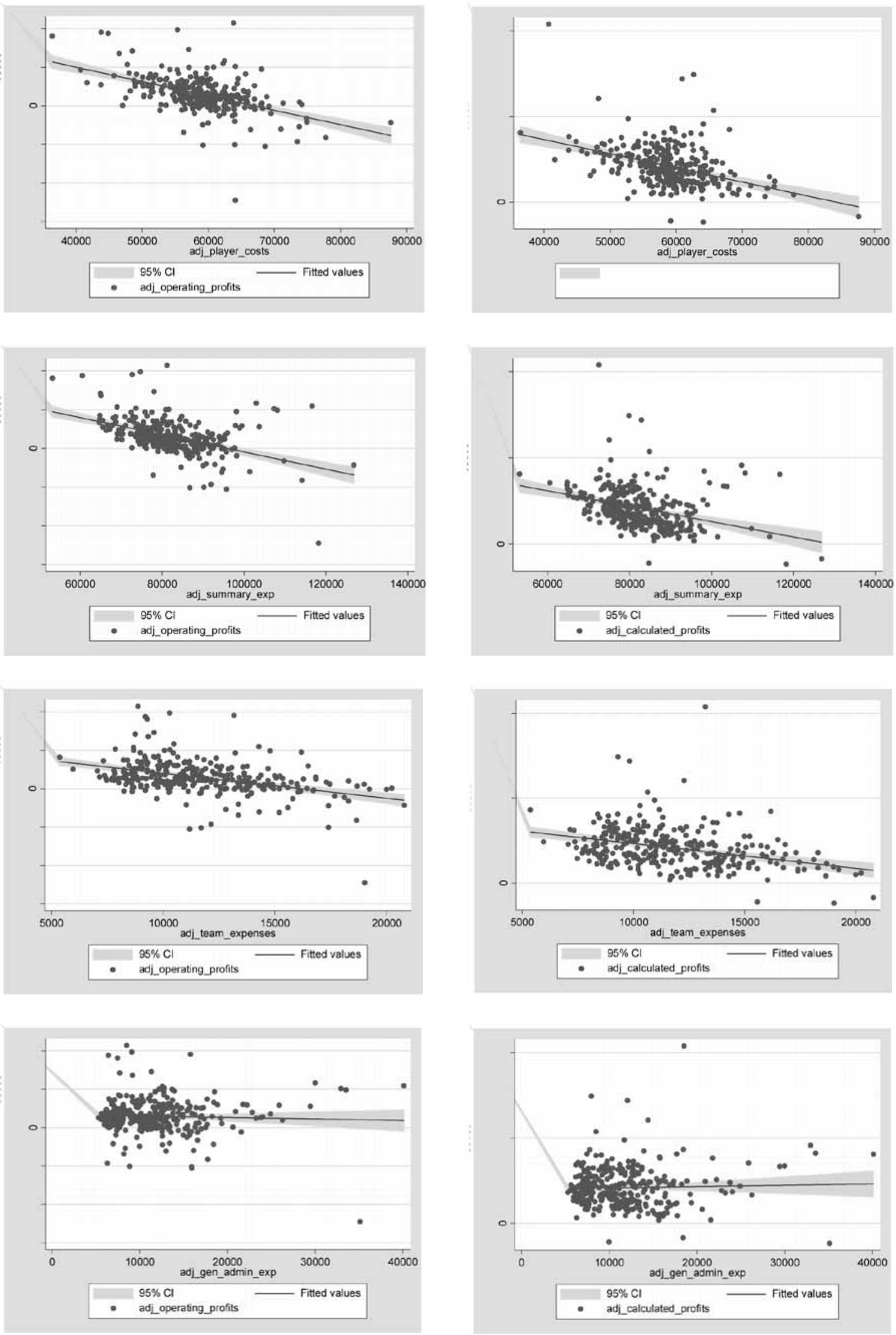

Figure $\mathbf{1 a}-\mathbf{1 h}-$ Graphs of inflation-adjusted profits and expenses. 

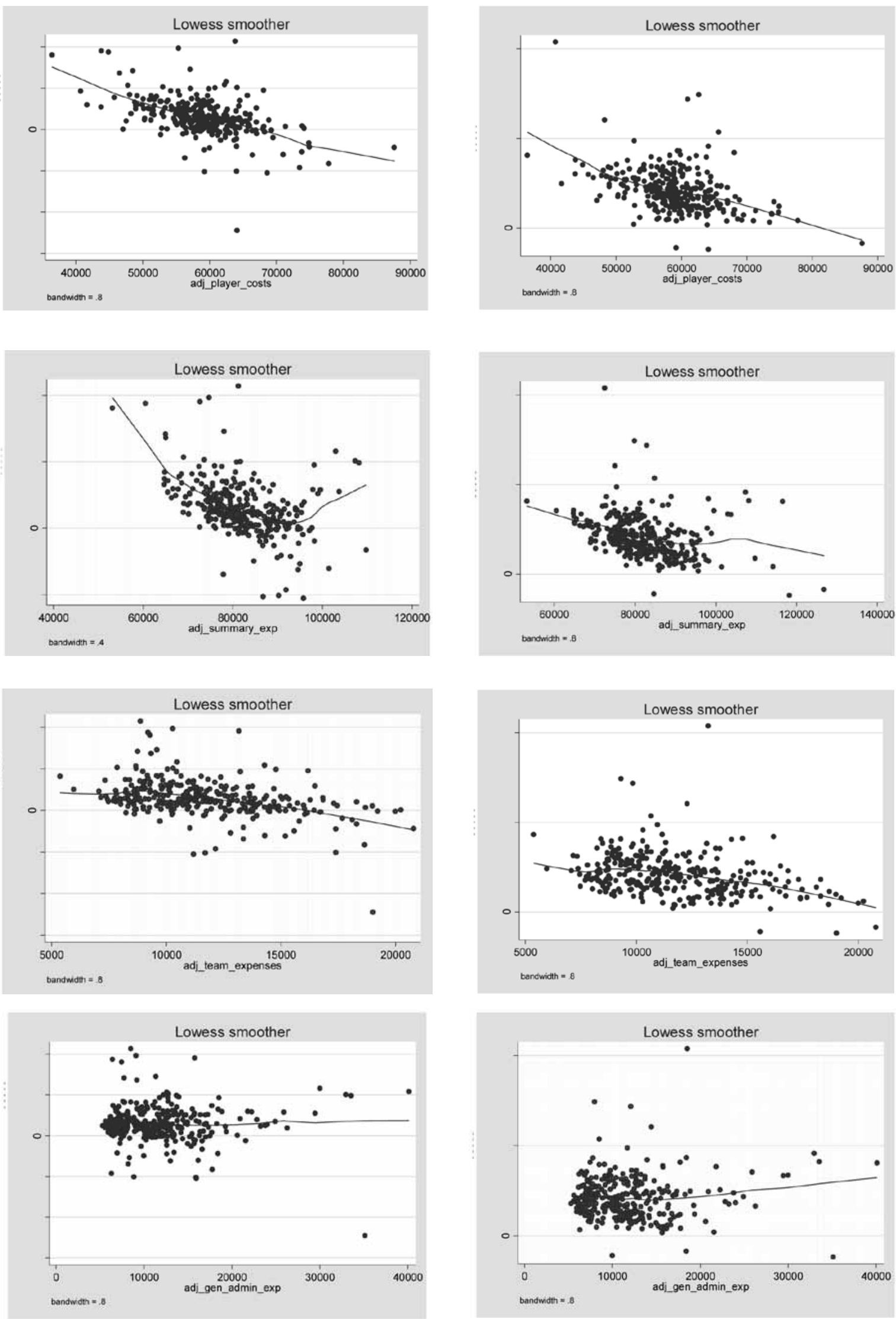

Figure $\mathbf{2} \mathbf{a}-\mathbf{2} \mathbf{h}-$ LOWESS graphs of inflation-adjusted profits and expenses. 
Table 3 Adjusted Calculated Profits and Adjusted Operating Profits (in 1998 Dollars)

\begin{tabular}{|c|c|c|c|c|}
\hline Model & $\begin{array}{l}\text { Adjusted Calculated } \\
\text { Profits with Player } \\
\text { Costs }\end{array}$ & $\begin{array}{l}\text { Adjusted Calculated } \\
\text { Profits with } \\
\text { Summary Expenses }\end{array}$ & $\begin{array}{l}\text { Adjusted Operating } \\
\text { Profits with Player } \\
\text { Costs }\end{array}$ & $\begin{array}{l}\text { Adjusted Operating } \\
\text { Profits with } \\
\text { Summary Expenses }\end{array}$ \\
\hline F-statistic & $14.84 * * * *$ & $12.42 * * * *$ & $28.16 * * * *$ & $11.88 * * * *$ \\
\hline R-squared & 0.21 & 0.17 & 0.25 & 0.25 \\
\hline Number of Observations & 309 & 309 & 309 & 309 \\
\hline Ramsey RESET test & $F=0.77$ & $\mathrm{~F}=0.82$ & $\mathrm{~F}=1.75$ & $F=1.42$ \\
\hline Cook-Weisberg test & $X^{2}=0.10$ & $\mathrm{X}^{2}=0.81$ & $X^{2}=1.30$ & $X^{2}=1.35$ \\
\hline Variance Inflation Factor test & Mean VIF $=1.08$ & Mean VIF = 1.11 & Mean VIF $=1.08$ & Mean VIF = 1.11 \\
\hline Dependent Variable & Adj. Calc. Profits & Adj. Calc. Profits & Adj. Op Profits & Adj. Op. Profits \\
\hline \multicolumn{5}{|l|}{ Independent Variables: } \\
\hline Constant & $-236,978 * * *$ & $-270,217 * * *$ & $-62,597$ & $-127,916$ \\
\hline $\begin{array}{l}\text { Player Costs Adjusted for } \\
\text { Inflation }\end{array}$ & $-0.82 * * * *$ & & $-1.84 * * * *$ & \\
\hline $\begin{array}{l}\text { Summary Expenses Adjusted } \\
\text { for Inflation }\end{array}$ & & $-0.46 * * * *$ & & $-1.13 * * * *$ \\
\hline $\begin{array}{l}\text { Summary Expenses Adjusted } \\
\text { for Inflation Squared }\end{array}$ & & & & $.0000199 * * *$ \\
\hline CMSA or MSA & $2,690 *$ & $3,612 * * *$ & 763 & 3,225 \\
\hline Year Stadium Opened & $154.6 * * *$ & $166.2 * * *$ & 94 & $119 *$ \\
\hline
\end{tabular}

Significance: *_- $10 \%$ level; **_ $5 \%$ level; ***-1\% level; ****_ $0.1 \%$ level.

an $\$ 820,000$ decrease in calculated profit. This is not surprising since nearly $70 \%$ of all revenues are shared in the NFL, but no player costs are shared. Thus, purchasing a talented player for $\$ 1$ million might generate over $\$ 1$ million in revenue. However, most of that will be shared with the league, making net franchise profits decrease.

An increase in summary expenses by $\$ 1$ million is associated with a $\$ 460,000$ decrease in adjusted calculated profits (see Table 3). In the regressions, annual number of wins and annual attendance were not included since they are intermediate outcomes stemming from player costs or summary expenses. Player costs and summary expenses were both positively correlated with wins and attendance. Population and the number of major professional sport teams were not statistically significant. Instrumental variables regression and linear regression with interaction terms were investigated with the results being similar to those reported here. The Ramsey RESET test for omitted variable bias was negative. The CookWeisberg test for heteroscedasticity was also negative. Variance-inflation factors were low, showing no multicollinearity issues in Table 3 except for the polynomial (last column).

However, the CMSA dummy variable was significant and positive in the full regressions. Finally, as a stadium gets older, adjusted calculated profits decrease by about $\$ 160,000$ per year. As expected and mentioned above, the R-square only explains about $20 \%$ of the variation in profits. The goodness-of-fit for the adjusted operating profits regressions (columns 3 and 4) is higher with R-square of
0.25 . An interesting finding is that the regression examining operating expenses (last column) is U-shaped (as suggested by the corresponding LOWESS regression). It has a minimum at about $\$ 115,000$ (which is on the higher end of adjusted summary expenses across the teams).

Table 4 depicts the analysis of the variables which were not adjusted for inflation. Multicollinearity was significant in Table 4. This is not surprising given the many variables increasing over time (simply because of inflation) that would be correlated together in Table 4. Table 3 accounted for that by using inflation-adjusted variables. The findings in Table 4 were somewhat similar to those in Table 3, but it appears that multicollinearity issues caused the coefficients to be different than those in Table 3 (because multicollinearity causes t-statistics to be artificially high, making it appear that a variable is significant, when it might not be). As a result, the coefficients, while technically unbiased, have a very broad confidence interval. Yearly indicator variables were used to account for the annual growth in overall franchise expenses in the NFL, with each being statistically significant (p.<.001), with 1989 as the comparison year. The variables of interest, player costs and summary expenses, both had negative impacts on operating profits and calculated profits and were statistically significant ( $\mathrm{p}$. $<.01)$. The full models were all statistically significant and had R-squares ranging from 0.36 to 0.44 . The results in Table 3 statistically have a stronger fit, but Table 4 is included to show how the raw data (i.e., not adjusted for inflation) performed. 
Table 4 Operating Profits and Calculated Profits (in Current Dollars)

\begin{tabular}{|c|c|c|c|c|}
\hline Model & $\begin{array}{l}\text { Operating Profits with } \\
\text { Player Costs }\end{array}$ & $\begin{array}{l}\text { Operating Profits with } \\
\text { Summary Expenses }\end{array}$ & $\begin{array}{l}\text { Calculated Profits } \\
\text { with Player Costs }\end{array}$ & $\begin{array}{l}\text { Calculated Profits } \\
\text { with Summary } \\
\text { Expenses }\end{array}$ \\
\hline F-statistic & $12.36 * * * *$ & $11.60 * * * *$ & $9.62 * * * *$ & $9.72 * * * *$ \\
\hline R-squared & 0.39 & 0.36 & 0.44 & 0.38 \\
\hline $\begin{array}{l}\text { Number of Observa- } \\
\text { tions }\end{array}$ & 309 & 309 & 309 & \\
\hline Ramsey RESET test & $F=1.58$ & $F=1.87$ & $\mathrm{~F}=2.01$ & 1.97 \\
\hline Cook-Weisberg test & $X^{2}=1.42$ & $X^{2}=1.54$ & $X^{2}=1.79$ & $X^{2}=1.01$ \\
\hline $\begin{array}{l}\text { Variance Inflation } \\
\text { Factor test }\end{array}$ & Mean VIF $=2.87$ & Mean VIF $=6.52$ & Mean VIF $=2.87$ & Mean VIF $=6.52$ \\
\hline Dependent Variable & Operating Profits & Operating Profits & Calculated Profits & Calculated Profits \\
\hline \multicolumn{5}{|l|}{ Independent Variables: } \\
\hline Constant & $-168,299 * * *$ & $-146,546 * * *$ & $-245,885 * * *$ & $-275,407 * * *$ \\
\hline Player Costs & $-0.655 * * * *$ & & $-.935 * * *$ & \\
\hline Summary Expenses & & $-1.09 * * *$ & & $-0.450 * * *$ \\
\hline $\begin{array}{l}\text { Summary Expenses } \\
\text { Squared }\end{array}$ & & $5.88 \mathrm{e}-06 * * *$ & & \\
\hline CMSA or MSA & $1,629 *$ & $1,346 * * *$ & $2,434 *$ & $3,111 * *$ \\
\hline Year Stadium Opened & $93 * * *$ & $86^{* * *}$ & $136 * * *$ & $149 * * *$ \\
\hline Year Indicator 1990 & $7,150 * * * *$ & $8,495 * * * *$ & $8,307 * * * *$ & $7,210 * * * *$ \\
\hline Year Indicator 1991 & $9,267 * * * *$ & $10,835 * * * *$ & $12,872 * * * *$ & $9,944 * * * *$ \\
\hline Year Indicator 1992 & $10,456^{* * * *}$ & $12,334 * * * *$ & $17,350 * * * *$ & $12,630 * * * *$ \\
\hline Year Indicator 1993 & $17,708 * * * *$ & $17,381 * * * *$ & $24,752 * * *$ & $14,186 * * *$ \\
\hline Year Indicator 1994 & $18,166 * * * *$ & $20,132 * * * *$ & $23,790 * * * *$ & $16,866 * * * *$ \\
\hline Year Indicator 1995 & $20,312 * * * *$ & $22,389 * * * *$ & $25,573 * * * *$ & $18,171 * * * *$ \\
\hline Year Indicator 1996 & $21,382 * * * *$ & $22,340 * * * *$ & $30,218 * * * *$ & $20,750 * * * *$ \\
\hline Year Indicator 1997 & $23,257 * * * *$ & $24,749 * * * *$ & $32,351 * * * *$ & $23,577 * * * *$ \\
\hline Year Indicator 1998 & $38,501 * * * *$ & $35,332 * * * *$ & $52,456 * * * *$ & $39,469 * * * *$ \\
\hline Year Indicator 1999 & $39,599 * * * *$ & $31,872 * * * *$ & $61,352 * * * *$ & $44,132 * * * *$ \\
\hline
\end{tabular}

Significance: *-10\% level; **_-5\% level; ***_- $1 \%$ level; ****-0.1\% level.

There was a clear negative relationship between profit and summary expenses (Table 4). Stadium characteristics and a measure of market size appeared to affect profitability, but the impact of expenses on profits was greater. An analysis of interaction terms and an analysis of polynomials of the different expense categories revealed no significant findings, except for a quadratic on Summary Expenses for the Operating Profits model in Table 4. Solving for the minimum point on the quadratic leads to a minimum Operating Profits where Summary Expenses equals about $\$ 93$ million. This is consistent with the Figure 2c.

An examination of linear regressions and LOWESS by year showed similar results. In $100 \%$ of the 44 annual linear regressions containing operating profits or calculated profits versus player payroll or summary expenses and control factors, the coefficient on the expense category was negative, with $57 \%$ being statistically significant. In all 11 of the LOWESS regressions of annual operating profit versus player payroll, the slope of the nonparametric relationship was negative. In six of the analyses of annual operating profit versus summary expenses, the relationship was negative, while in the remaining five analyses, it was U-shaped. Similar results were obtained using calculated profits.

An analysis of the parameters $\beta$ and $\gamma$ is shown in Table 5. The simple univariate regressions (with constant terms) yielded significant results for both the model and the independent variables. However, the models for revenues and expenses have low R-squared goodness-of-fit parameters. This is partially because these are single variable models without other explanatory variables. The dependent variables were expressed in thousands of dollars; therefore, interpretation of the coefficients needs to 
Table 5 Assessment of the Sensitivity of Revenues and Expenses to Winning

\begin{tabular}{|c|c|c|}
\hline Model & $\begin{array}{l}\text { Adjusted Local } \\
\text { Revenues }\end{array}$ & $\begin{array}{l}\text { Adjusted } \\
\text { Summary } \\
\text { Expenses }\end{array}$ \\
\hline F-statistic & $33.95 * * * *$ & $17.74 * * * *$ \\
\hline R-squared & 0.10 & 0.06 \\
\hline $\begin{array}{l}\text { Number of Obser- } \\
\text { vations }\end{array}$ & 309 & 309 \\
\hline $\begin{array}{l}\text { Dependent Vari- } \\
\text { able }\end{array}$ & $\begin{array}{l}\text { Adj. Local Rev- } \\
\text { enues }\end{array}$ & $\begin{array}{c}\text { Adj. Summary } \\
\text { Expenses }\end{array}$ \\
\hline \multicolumn{3}{|l|}{$\begin{array}{l}\text { Independent Vari- } \\
\text { ables: }\end{array}$} \\
\hline Constant & $32,420 * * * *$ & $76,496 * * * *$ \\
\hline Team Wins & $1,142.6 * * * *$ & $752.7 * * * *$ \\
\hline \multicolumn{3}{|l|}{ Parameters: } \\
\hline$\alpha$ & $0.6^{1}$ & \\
\hline$\beta$ & $1,142,622^{2}$ & \\
\hline$\gamma$ & $752,685^{3}$ & \\
\hline$\alpha * \beta$ & 685,573 & \\
\hline$\alpha * \beta-\gamma$ & $-67,112$ & \\
\hline
\end{tabular}

Significance: $*_{-}-10 \%$ level; $* *_{-} 5 \%$ level; $* * *_{-} 1 \%$ level; $* * * *-0.1 \%$ level.

${ }^{1}$ Based on the revenue sharing rules in the NFL during the $1990_{\mathrm{s}}$.

${ }^{2}$ The coefficient on team wins is multiplied by 1,000 to account for Adjusted Local Revenues represented in thousands of dollars, not actual dollars.

${ }^{3}$ The coefficient on team wins is multiplied by 1,000 to account for Adjusted Summary Expenses represented in thousand of dollars, not actual

be adjusted. For instance, during the 1990s, an additional win yielded $\$ 1.14$ million dollars of local revenue but also cost a franchise $\$ 752,685$. Given that $60 \%$ of local revenues are kept by the franchise (with $40 \%$ being shared with other teams), the net revenues from an additional win $\left(\alpha^{*} \beta\right.$ ) were $\$ 685,573$. An analysis of equation (4) showed that the incremental change in profits from winning one more game (and having to share some of those revenues and incur the full cost of creating them) was $-\$ 67,112$. This was consistent with the findings in Figures 1 and 2 and Tables 3 and 4.

\section{Discussion}

Across NFL teams, there is a wide range of player payroll costs and summary expenses. Based upon the current data analysis, it appears that some NFL owners choose to free ride while others do not, with some spending more on players than maximizing profits would warrant. Overall, the purpose of the multiple methods used to investigate various definitions of expenses and various definitions of profit show that spending less produces higher profits (other than the U-shaped regression between adjusted operating profits and adjusted summary expenses). Empirically, the NFL is structured to slightly create the incentive to keep costs down by spending less. Theoretically, this is consistent with the notion that some teams will maximize profits (and spend less) while others will maximize wins (or some combination of the two) causing the relationship across the league to be downward sloping between profits and expenses.

The high spending owners are presumably sportfocused owners. Another possible explanation for this behavior is the characteristic of a team's market. Owners in larger markets, more so than owners in smaller markets, may spend more to create higher quality teams because it is in their economic interest (Gerrard, 2005; Késenne, 2000; Rascher, 1997). Yet, the LOWESS graphs and regressions results show that this is not actually profitable, but instead only produces more wins. Only in one case is the profit versus expenses function U-shaped indicating that spending a lot or a little is most profitable, but being in the middle between the extremes is not. This coincides with the general finding in sport economics research that population is an important factor in determining demand. Therefore, an additional unit of quality for the product being sold will increase the actual demand for tickets (and related merchandise, concessions, etc.) by a larger number in a market with a higher population. Thus, there are more potential fans to be acquired by increasing team quality in a larger market.

While market characteristics do impact NFL profitability, these characteristics do not completely explain the findings that some teams spend less on team quality but reap higher profits. The correlation between population and team expenses is positive and significant, but small (e.g., the correlation between population and summary expenses, team expenses, and player costs is $0.13,0.30$, and 0.14 , respectively). In addition, higher costs in larger population centers might simply result from the higher cost of doing business in more urban areas.

A second possible explanation relates to each owner's motivation. Certainly, each owner desires to experience on-field success and most owners would like to spend more on team quality to own a competitive sport team. In fact, many owners are able to spend more because they have significant wealth beyond their ownership of an NFL team. For example, Jim Irsay, owner of the Indianapolis Colts, sold personal stock and real estate holdings to pay \$100 million in signing bonuses from 1999 through 2008 (Burke, 2008). However, some owners may not have the desire or the ability to use outside funding sources. A number of owners have a large portion of their wealth invested in their NFL franchise and are more likely to treat their team as a profit-maximizing business. These owners might find it more profitable to free ride than to spend for a high performance team. 
An examination of NFL ownership during the 1990s demonstrates that free riding occurred in specific cases. Two of the teams that appeared to have been free riding the most were the Cincinnati Bengals and the Chicago Bears (see Table 6). In 1991, Mike Brown became the majority owner of the Bengals, a team that his father, Paul Brown, founded. The Chicago Bears were owned by Virginia McCaskey, team founder George Halas's daughter. It is believed that their stake in the NFL constitutes the majority of their wealth (Ludwig, 2008; Mulligan, 2007). The Pittsburgh Steelers, to a lesser extent, were also free riders during this time period. The Steelers were owned by Dan Rooney, the son of founder Art Rooney. From an efficiency perspective, the Steelers were able to succeed on the field (winning 10 games or more in five of the 11 seasons) with low expenditures compared with other NFL teams.

The Tampa Bay Buccaneers were, perhaps, the most egregious of all free riders. The Buccaneers were owned by Hugh Culverhouse until 1995, when Malcolm Glazer purchased the franchise. Clearly, Malcolm Glazer does not fit the mold of an owner whose primary financial investment is an NFL club as he is the 462nd wealthiest individual in the world (Kroll, 2008). Though it appears that some owners of "family-operated" teams appear to free ride for economic "necessity," some wealthier owners may free ride for profit maximization.

Ultimately, the decision to potentially free ride is idiosyncratic and depends on the motivation of each owner. From the perspective of the league, however, having incentives to reduce payroll and on-field quality

\section{Table 6 Team Ranking of Profit Divided by Summary Expenses (Sorted Highest to Lowest)}

\begin{tabular}{ccccc}
\multicolumn{5}{c}{ Franchise and Ranking of Highest Profit divided by } \\
Summary Expenses
\end{tabular}

Note. The NFL averaged 29 teams over the time period.

${ }^{1}$ A conversation by one of the authors with an NFL team official revealed that the NFL is concerned that certain teams rely extensively upon the rest of the league to generate revenues, especially since some of those teams are extremely profitable. to the detriment of the rest of the league is problematic. It is in the interest of the league to establish policies that help keep costs under control while still maintaining quality and competitive balance. In particular, the salary cap and revenue-sharing policies help lower player salaries and other costs (e.g., team marketing costs). A problem exists when some teams are primarily carrying the burden of maintaining and growing the league's brand (e.g., the Dallas Cowboys), while others are harming, or free riding on, the brand (e.g., the Cincinnati Bengals). From a league's perspective, creating incentives to save costs is good, but allowing teams to reduce on-field quality to do so can be detrimental.

Until 2010, the NFL had a policy that forced teams to spend a minimum amount on player payroll (along with its player cap) yet free riding existed. With the owners opting to end the current CBA (Clayton, 2008), the salary floor and cap have been removed for at least the 2010 season. With the elimination of the salary floor, additional teams may now be inclined to free ride. Ultimately, this may harm the league's brand reducing the value of the league as a whole and the value of its member franchises as well.

Teams also are not required to spend in other areas that impact quality such as scouting, coaching, training facilities, and staff. As it is likely not feasible to regulate all team expenditures, another solution, one that the league has recently implemented, is to exempt a majority of some revenue streams from the revenue-sharing pool. The NFL's policy covering stadium-related revenues allows owners to keep almost all of the nonticket revenue generated by the stadium itself. Major League Baseball has enacted a similar policy. By allowing owners to retain a majority of stadium revenues, an incentive is provided for the owners to build new stadiums. Simultaneously, their motivation to field a competitive team increases so that the owner can then leverage the value of the new stadium (e.g., increase luxury suite and club seat sales). Other professional leagues face these same problems. However, these leagues share a lower percentage of their revenues so the problem is not as severe.

Ultimately the NFL has been extremely successful since its decision to equally share its national television revenues in 1960. John Mara, New York Giants co-owner, stated, "you could argue that we deserve a bigger piece of the pie, but it's the reason that the NFL is the strongest professional league on the planet." (Burke, 2003, para. $4)$. The willingness to generously share revenues among NFL owners has contributed to the continual and rapid growth of league and team revenues and the league's brand strength. However, the presence of free riding could undermine the league's financial performance. The new revenue-sharing model that will be negotiated beginning in 2010 or 2011 may become even more important to the league as average team operating income was reduced $24 \%$ since its peak during the 2002 season as a result of changes to the model under the 2006-2010 CBA (Badenhausen, Ozanian, \& Settimi, 2008). 


\section{Directions for Future Research}

While previous papers have investigated free riding and revenue sharing in professional sport, these papers have primarily focused on the impact of revenue sharing on competitive balance (Késenne, 2000; Palomino \& Rigotti, 2000; Szymanski \& Késenne, 2004) and attendance (Fort \& Quirk, 1995; Marburger, 1997; Rascher, 1997; Vrooman, 1996). This paper has advanced existing knowledge regarding free riding in professional sport by directly examining the impact of free riding upon NFL franchise profitability. Moreover, it is the first article with such an extensive data set allowing a detailed understanding of which owners free ride. Perhaps surprisingly, the free-riding teams are not the ones in small markets. Further, the need for expanding research related to free riding was called for by Lopatka and Herndon (1997) and Fort and Quirk (1995). However, there remain areas of investigation that should take place.

The causes of the observed free riding in the NFL should be closely examined especially, as the league prepares to negotiate a new CBA and develops a new revenue-sharing system. Perhaps there are systematic or structural reasons beyond each owner's personal ownership objectives that result in free riding. An analysis of the degree of revenue sharing each year and whether it is a significant predictor of free riding is warranted as well. Similar analyses of other leagues would help determine whether free riding is a widespread problem. Anecdotally, it appears that Donald Sterling, owner of the Los Angeles Clippers, free rides in the NBA ("\#25 Los Angeles Clippers," 2008). Various MLB teams also appear to free ride occasionally. After its success during the late 1980s and early 1990s, the Oakland Athletics cut payroll and team quality significantly and business decisions became more driven by the pursuit of profits. Even though the team's performance was poor, the ownership group was satisfied (Lewis, 2003).

Also, the recent increase in revenue sharing in MLB has uncovered a number of teams, such as the Milwaukee Brewers and Tampa Bay Rays, which were receiving revenue-sharing money while not improving the quality of their major league on-field product (Zimbalist, 2004). For example, the Milwaukee Brewers revenue-sharing portion grew from $\$ 2$ million to $\$ 18$ million between 2002 and 2004. During the same timeframe, the Brewers' payroll decreased from $\$ 50$ million to $\$ 28$ million, which was the lowest in MLB (Badenhausen, 2004). The Pittsburgh Pirates reportedly received nearly $\$ 18$ million in revenue-sharing money in 2005 , yet the team cut its payroll approximately \$25 million between 2001 and 2005 . Kevin McClatchy, former majority owner of the Pirates, stated that he used his portion of revenue-sharing money to pay off existing debts and not to improve the team's quality (Kovacevic, 2005). As a result of these ownership actions and given the drastic changes in revenue sharing that have taken place, a longitudinal analysis regarding revenue sharing in MLB needs to be undertaken.

The National Hockey League has historically shared little of its revenue. In 2003, it was reported that the league shared 9\% of its revenue ("How the NFL levels...," 2003). The NHL's poor economic model led to sufficient revenue disparities between teams to cause a player lockout that eventually canceled the 2004-2005 season. Under the new CBA with its players, a hard salary cap and floor was implemented as was increased revenue sharing ("Collective bargaining agreement...," 2005). The NHL's revenue-sharing plan requires teams to maintain a set attendance level to qualify for certain revenue-sharing payments. This, combined with a salary floor, ensures some effort to invest in team quality. Ultimately, every sport league needs to determine the optimal revenuesharing model to ensure league financial viability while also preventing free riding.

\section{References}

\#25 Los Angeles Clippers. (2008, December 3). Forbes. Retrieved from http://www.forbes.com/lists/2008/32/ nba08_Los-Angeles-Clippers_322952.html

Alesia, M. (2002, October 20). Expert: Colts' claim is suspect. The Indianapolis Star. Retrieved from www.indystar.com

Alexander, D.L., \& Kern, W. (2004). The economic determinants of professional sports franchise values. Journal of Sports Economics, 5, 51-66.

Badenhausen, K. (2004, November 1). Buddy system. Forbes. Retrieved from http://www.forbes.com/business/ forbes/2004/1101/056a.html

Badenhausen, K., Ozanian, M., \& Settimi, C. (2008, September 11). The richest game. Forbes. Retrieved from http://www. forbes.com/2008/09/10/nfl-team-valuations-biz-sportsnfl08_cz_kb_mo_cs_0910intro.html

Barrett, W. (2003, September 1). Going back to Houston: Like so many of America's sports-hungry cities, Houston, Tex., saw its longtime National Football League team move to another region of the country, only to have it replaced by another franchise. USA Today Magazine (Society for the Advancement of Education). Retrieved from http://www. usatodaymagazine.net

Bell, J. (2004, July 5). NFL's tug-of-war over revenue. USA Today. Retrieved from http://www.usatoday.com/sports/ football/nfl/2004-07-05-revenue-cover_x.htm

Bell, J. (2006, March 8). NFL owners accept player union proposal with 30-2 vote. USA Today. Retrieved from http://www.usatoday.com/sports/football/nfl/2006-03-08labor_x.htm

Bloom, H. (2006, October 24). The good news a new MLB labor accord, the bad news a new MLB labor accord II. Sports Business News. Retrieved from http://sportsbiznews. blogspot.com/2006_10_22_archive.html

Brown, M.T., Nagel, M.S., McEvoy, C.D., \& Rascher, D.A. (2004). Revenue and Wealth Maximization in the National Football League: The impact of stadia. Sport Marketing Quarterly, 13, 227-235.

Burke, M. (2003, August 29). Turning \$500 into a \$573 million NFL team. Forbes. Retrieved from http://www.forbes.com/ forbes/2003/08/29/cz_mb_8029giants_print.html

Burke, M. (2008, September 29). Colt 45. Forbes. Retrieved from http://www.forbes.com/forbes/2008/0929/083_print.html 
Cat, F. (n.d.). Mikebrownsucks.com mission statement. Retrieved from http://www.mikebrownsucks.com/mission_statement.html

Clayton, J. (2008, May 20). NFL owners vote unanimously to opt out of labor deal. Retrieved from http://sports.espn. go.com/nfl/news/story?id=3404596

Cleveland, W.S. (1979). Robust locally weighted regression and smoothing scatterplots. Journal of the American Statistical Association, 74, 829-836.

Collective bargaining agreement between the National Hockey League and the National Hockey League Players' Association. (2005, July 22). Retrieved from http://www.nhl.com/ cba/2005-CBA.pdf

Daugherty, P. (2008, November 2). Doc calls Mike Brown out. Cincinnati Enquirer. Retrieved from http://news.cincinnati. com/article/20081102/COL03/811020446

Donatelli, J. (2003, December). Surf's up: Los Angeles fans do indeed love pro football, but they have better things to do than sit around and worry about landing a new team. Football Digest. Retrieved from http://findarticles.com/p/ articles/mi_m0FCL/is_4_33/ai_110312192

Dosh, K. (2007, June 28). Does revenue sharing in MLB foster competitive balance? Retrieved from http://mvn.com/ mlb-braves/2007/06/28/does-revenue-sharing-in-mlbfoster-competitive-balance/

Fort, R.D. (2003). Sports economics. Upper Saddle River, NJ: Prentice Hall.

Fort, R.D., \& Quirk, J. (1995). Cross-subsidization, incentives, and outcomes ion professional team sports leagues. Journal of Economic Literature, 33, 1265-1299.

Foster, G., Greyser, S.A., \& Walsh, B. (2006). The business of sports. Mason, $\mathrm{OH}$ : Thompson South-Western.

Gerrard, B. (2005). A resource-utilization model of organizational efficiency in professional sports teams. Journal of Sport Management, 19, 143-169.

Harris, D. (1986). The league: The rise and decline of the NFL. New York: Bantam.

Helyar, J. (2006, March 6). Labor peace threatened by rift between owners. Retrieved from http://sports.espn.go.com/ nfl/news/story?id=2354095

How the NFL levels the playing field. (2003, January 27). Business Week. Retrieved from http://www.businessweek.com/ magazine/content/03_04/b3817003.htm

Jerry Jones fined six-figures for revenue-sharing comment. (2009, September 13). Retrieved from http://www.sportingnews.com/nfl/article/2009-09-13/jerry-jones-fined-sixfigures-for-revenue-sharing-comment

Késenne, S. (2000). Revenue sharing and competitive balance in professional team sports. Journal of Sports Economics, 1, 56-65.

Kovacevic, D. (2005, May 1). The debate about the Pirates' demise always comes back to team payroll: In the age of revenue sharing and television contracts, how much are the Pirates making and what are they doing with the profits? Pittsburgh Post-Gazette, p. C-1.

Kroll, L. (2008, March 5). The world's billionaires. Forbes. Retrieved from http://www.forbes.com/lists/2008/03/05/ richest-people-billionaires-billionaires 08 -cx lk_0305billie_land.html
Lewis, M. (2003). Moneyball. New York: W.W. Norton \& Company.

Lopatka, J.E., \& Herndon, J.B. (1997). Antitrust and sports franchise ownership restraints: A sad tale of two cases. The Antitrust Bulletin, 42, 749-791.

Ludwig, C. (2008, November 24). Vote now: Bob Castellini or Mike Brown? Dayton Dailey News. Retrieved from http:// www.daytondailynews.com/o/content/shared-gen/blogs/ dayton/chickludwig/entries/2008/11/24/vote_now_bob_ castellini_or_mik.html

Marburger, D.R. (1997). Gate revenue sharing and luxury taxes in professional sports. Contemporary Economic Policy, $15,114-123$.

Martzke, R. (2005, February 4). NFL still working to finalize TV rights deal. USA Today. Retrieved from http://www. usatoday.com/sports/football/nfl/2005-02-04-tagliabuetv_x.htm

Maske, M. (2005, April 19). TV deals show league's might. Washington Post. Retrieved from http://www.washingtonpost.com/wp-dyn/articles/A825-2005Apr19.html

Mason, D.S. (1997). Revenue sharing and agency problems in professional team sport: The case of the National Football League. Journal of Sport Management, 11, 203-222.

Miller, P.A. (2009). Facility age and ownership in major American team sports leagues: The effect on team franchise values. International Journal of Sport Finance, 4, 176-191.

MLB at a crossroads, day 214: Twins will play through '03. (2002, June 7). SportsBusinessDaily. Retrieved from http://www.sportsbusinessdaily.com/index. $\mathrm{cfm} ?$ fuseaction $=$ article . main $\&$ articleId $=66626 \&$ keywor $\mathrm{d}=$ twins, \%20lawsuit, \%20contraction

Monk, D. (2002). Are losers liable? Cincinnati Business Courier, 19(34), 1.

Mulligan, M. (2007, January 25). He'd be a proud Papa Bear. Chicago Sun-Times. Retrieved from http://www.suntimes. com/super/mulligan/229185,CST-SPT-mully25.article\#

National Football League collective bargaining agreement. (2006, March 8). Retrieved from http://www.nflplayers. com/user/template $\cdot$ aspx $?$ fmid $=181 \& 1 \mathrm{mid}=622 \&$ pid $=0$ \&type $=1$

NFL team valuations. (2005). Forbes. Retrieved from http:// www.forbes.com/lists/2005/30/Income_1.html

O'Sullivan, T. (2002, September 25). The doom of McAdoo. Retrieved from http://www.hoopshype.com/articles/clippers_osullivan.htm

Palomino, F., \& Rigotti, L. (2000, November). The sport league's dilemma: Competitive balance versus incentives to win. Retrieved from University of California, Berkeley Institute of Business and Economic Research, Web site: http://repositories.cdlib.org/cgi/viewcontent. cgi article $=1021 \&$ context $=$ iber $/$ econ

Pappas, D. (2002, February 4). The numbers (part six): Profits and revenue sharing. Baseball Prospectus. Retrieved from http://www.baseballprospectus.com/ article.pho?articleid=1333

Questions and answers about the NFL labor talks. (2006, March 8). Retrieved from http://sports.espn.go.com/nfl/news/ story?id=2351462 
Rascher, D.A. (1997). A model of a professional sports league. In W. Hendricks (Ed.), Advances in the economics of sport (Vol. 2, pp. 27-76). Greenwich, CT: JAI Press.

Ross, S. (2000). Myths, realities, and creative approaches to antitrust and franchise relocation issues. Antitrust, 14, $57-62$.

Rovell, D. (2003, April 17). Owed to Donald Sterling. Retrieved from http://espn.go.com/nba/s/2003/0417/1540659.html

Scully, G.W. (1989). The business of Major League Baseball. Chicago, IL: University of Chicago Press.

Scully, G.W. (1995). The market structure of sports. Chicago, IL: University of Chicago Press.

Snel, A. (2005, April 20). As Rays whiff, front office scores. Retrieved from http://news.tbo.com/news/MGBHBR3UQ7E.html

Standings. (2008). Retrieved from http://www.nfl.com/standings

Szymanski, S., \& Késenne, S. (2004). Competitive balance and gate revenue sharing in team sports. The Journal of Industrial Economics, 52, 165-177.

The Oakland Raiders, Plaintiff, Cross-Defendant and Appellant, v. National Football League, Defendant, Cross-Complain- ant and Appellant; Paul Tagliabue et al., Defendants and Respondents. 2001. Ct. App. 2/2 B163115 Los Angeles County Super. Ct. No. BC206388.

Vrooman, J. (1996). The baseball players' labor market reconsidered. Southern Economic Journal, 63, 339-360.

Weir, T. (2002, October 16). New revenue likely won't help payrolls. USA Today. Retrieved from http://www.usatoday. com/sports/baseball/salaries/2002-10-16-revenue_x.htm

Weisman, L. (2006, March 5). NFL labor talks stall, free agency postponed again. USA Today. Retrieved from http://www.usatoday.com/sports/football/nfl/2006-03-05labor-talks_x.htm

Wertheim, L.J. (2007, November 27). The quiet owner: Paul Allen. Sports Illustrated. Retrieved from http://sportsillustrated.cnn.com/2007/writers/the_bonus/11/27/paul. allen1203/index.html

Zimbalist, A. (2001, August 20-26). Teams riding high, despite NFL's protest. SportsBusiness Journal, 4(18), 46.

Zimbalist, A. (2004, April 5). Break up the Yanks? We owe them thanks. SportsBusiness Journal. Retrieved from http:// www.sportsbusinessjournal.com/article/37925 
Copyright of Journal of Sport Management is the property of Human Kinetics Publishers, Inc. and its content may not be copied or emailed to multiple sites or posted to a listserv without the copyright holder's express written permission. However, users may print, download, or email articles for individual use. 